Article

\title{
Evaluation of the Immunosafety of Cucurbit[n]uril on Peripheral Blood Mononuclear Cells In Vitro
}

\author{
Ekaterina Pashkina ${ }^{1,2,3, *}$, Alina Aktanova ${ }^{1,3}$, Elena Blinova ${ }^{1}$, Irina Mirzaeva ${ }^{4}{ }^{\oplus}$, \\ Ekaterina Kovalenko $\left.{ }^{4}{ }^{(}\right)$, Nadezhda Knauer ${ }^{1,3}{ }^{-}$, Aleksandr Ermakov ${ }^{2}$ and Vladimir Kozlov ${ }^{1,2}$ \\ 1 Research Institute of Fundamental and Clinical Immunology, 14, Yadrintsevskaya st., \\ 630099 Novosibirsk, Russia; aktanova_al@mail.ru (A.A.); blinovaelena-85@yandex.ru (E.B.); \\ knauern@gmail.com (N.K.); niiki01@online.nsk.su (V.K.) \\ 2 Novosibirsk State Medical University, 52, Krasny Prospect, 630091 Novosibirsk, Russia; aleermak@mail.ru \\ 3 Institute of Chemical Biology and Fundamental Medicine SB RAS, 8, Lavrentiev ave., \\ 630090 Novosibirsk, Russia \\ 4 Nikolaev Institute of Inorganic Chemistry SB RAS, 3, Lavrentiev ave., 630090 Novosibirsk, Russia; \\ dairdre@gmail.com (I.M.); e.a.kovalenko@niic.nsc.ru (E.K.) \\ * Correspondence: pashkina.e.a@yandex.ru
}

Received: 16 June 2020; Accepted: 23 July 2020; Published: 27 July 2020

\begin{abstract}
Cucurbiturils (CB[n]s) are nanoscale macrocyclic compounds capable of encapsulating a molecule or part of a molecule by forming host-guest complexes. Integration of drugs with $\mathrm{CB}[\mathrm{n}]$ is used for the following purposes: controlling clearance; protection of the drug from biodegradation; targeted delivery to specific organs, tissues, or cells; reduction of toxicity; and improving solubility. One of the major problems encountered in the application of new drug delivery systems is lack of knowledge of their biological properties. $\mathrm{CB}[\mathrm{n}]$, unlike many other often toxic nanoparticles, has extremely low toxicity, even at high doses. However, many aspects of the biological actions of these nanoscale cavitands remain unclear, including the immunotropic properties. In this study, we investigated the immunotoxicity and immunomodulation properties of $\mathrm{CB}[\mathrm{n}]$. It was found that $\mathrm{CB}[7]$ and $\mathrm{CB}[6]$ did not decrease the viability of mononuclear cells at all tested concentrations from 0.1-1 mM. Overall, the results indicated an immunomodulatory effect of different concentrations of $\mathrm{CB}[\mathrm{n}]$. In the case of a longer cultivation time, $\mathrm{CB}[\mathrm{n}]$ had an immunostimulating effect, which was indicated by an enhancement of the proliferative activity of cells and increased expression of HLA-DR on lymphocytes.
\end{abstract}

Keywords: nanoparticles; cucurbiturils; immunosafety; immune cells

\section{Introduction}

The use of nanoscale drug delivery systems is one of the most promising areas in modern pharmaceutical science [1,2]. Drug delivery systems are used for a variety of reasons, including to control the drug clearance; to protect the drug from biodegradation; for targeted delivery to specific organs, tissues, or cells; to reduce toxicity; and to increase solubility. However, before the application in clinical practice, nanostructures and nanomaterials used as components for such drug delivery systems require a comprehensive and careful study of their properties and biological activity. This research includes a study of the immunotropic properties of these substances because the cells of the immune system are the most sensitive to the damaging effect of nanomaterials.

One of the possible ways to create systems for the delivery of drugs is the use of nanoscale cavitands capable of host-guest complexation with drugs. Complexes of drugs can be obtained with various cavitands, including cyclodextrins, calixarenes, cucurbit[n]urils (CB[n]s), crown ethers, 
and cryptophanes. $\mathrm{CB}[\mathrm{n}] \mathrm{s}$ have a number of advantages, such as low toxicity, the ability to form stable complexes with various compounds, and the ability to bind with both hydrophobic and positively charged molecules. The formation of complexes of $\mathrm{CB}[\mathrm{n}] \mathrm{s}(n=6,7$, and 8$)$ with drugs can result in several benefits [3-8], including increasing the stability of the drug and reducing the rate of degradation in vivo, increased solubility, altered clearance, enabling a change in the route of administration (from parenteral to oral), and taste masking. The cavities of CB[6] and CB[7] (Figure S1 in Supplementary) are large enough to encapsulate transition metal complexes and small peptides [9]. Known examples of encapsulated drugs include cisplatin [10], oxaliplatin [11], and tuftsin [12]. However, to date, the effect of complexation with $\mathrm{CB}[\mathrm{n}]$ on the biological properties of drugs is not completely clear.

Potential drug carriers should have low toxicity. In vitro and in vivo studies have shown that $\mathrm{CB}[\mathrm{n}] \mathrm{s}$ and their derivatives are inert and have practically no toxicity. At concentrations of up to 1 $\mathrm{mM}, \mathrm{CB}[7]$ did not show cytotoxic activity toward various human and animal cell lines [13]. Moreover, the encapsulation of a drug into the cavity of $\mathrm{CB}[\mathrm{n}]$ may reduce the toxicity of the drug $[11,14,15]$. Safety studies of $\mathrm{CB}[\mathrm{n}]$ in vivo have also been performed [16-22]. Although CB[7] was found not hepatotoxic at $750 \mu \mathrm{M}$, it was cardiotoxic and affected motor activity at lower concentrations, and it was found even lethal after 48 hours, indicating a chronic toxicity [18].

When laboratory mice were administered CB[7], the maximum tolerated dose was $250 \mathrm{mg} / \mathrm{kg}$. Intravenous administration of $\mathrm{CB}[\mathrm{n}]$ is limited because of the low solubility, and not because of the development of side effects. For oral administration of a mixture of $\mathrm{CB}[6]-\mathrm{CB}[8]$, the maximum tolerated dose was $600 \mathrm{mg} / \mathrm{kg}$ [17]. In another study of the biocompatibility of CB[7], Zhang et al. showed that a single oral dose of $\mathrm{CB}$ [7] at $5 \mathrm{~g} / \mathrm{kg}$ did not lead to a significant decrease in animal body weight within 21 days after administration [22]. $\mathrm{CB}$ [7] has a dose-dependent toxicity. The administration of $\mathrm{CB}$ [7] at $750 \mathrm{mg} / \mathrm{kg}$ intraperitoneally and $200 \mathrm{mg} / \mathrm{kg}$ intravenously led to the rapid death of animals within a few minutes, while injections of $500 \mathrm{mg} / \mathrm{kg}$ peritoneally and $150 \mathrm{mg} / \mathrm{kg}$ intravenously did not result in any effects. Hematological tests, as well as tests for biochemical markers of hepatic and renal function, on blood taken from mice 21 days after the administration of CB[7] orally, intraperitoneally, and intravenously showed normal ranges of values, which were comparable to the control group. In addition, histological analysis of sections of the main organs (including the heart, liver, spleen, lungs, and kidneys) and the gastrointestinal tract revealed no visible injuries or signs of inflammation [22]. The biocompatibility of $\mathrm{CB}[6]$ only has not been studied.

Thus, the low toxicity and biomedical safety of $\mathrm{CB}[\mathrm{n}] \mathrm{s}$ have been demonstrated in various studies. However, to date, several aspects of the safety of $\mathrm{CB}[\mathrm{n}] \mathrm{s}$ remain unclear, including the effects on the immune system. It is important to determine the effect of nanoparticles on the immune system because the cells of the immune system are the most sensitive to the damaging effect of nanomaterials. In this study we investigated the in vitro immunotoxicity and immunomodulation properties of $\mathrm{CB}[6]$ and $\mathrm{CB}[7]$.

\section{Results and Discussion}

CB[6] and CB[7] did not have a cytotoxic effect on PBMCs at all doses tested from 0.1 to $1 \mathrm{mM}$ (Figure 1). The data obtained were in agreement with the literature data, which indicates that CB[n] is non-toxic in cells and human and animal tissues at micromolar concentrations $[9,13]$. Based on these data, we used concentrations of less than $1 \mathrm{mM}$ for further experiments.

The next step was to study the effect of $\mathrm{CB}[\mathrm{n}]$ on the relative amount of PBMCs in different phases of the cell cycle, including with spontaneous (Table 1) and anti-CD3 antibody-induced (Table 2) proliferation. Previously, we showed that $\mathrm{CB}[7]$ had no effect on the cell cycle, but only one concentration of $\mathrm{CB}[7]$ was used in this work [12]. In the present study, $\mathrm{CB}[6]$ and $\mathrm{CB}[7]$ did not affect the ratio of cells in different phases of the cell cycle and did not increase the relative number of sub-cycling hypodiploid cells in non-activated PBMCs at all tested concentrations. It was also shown that CB[6] and CB[7] did not affect the percentage of PBMCs in different phases of the cell cycle in cells activated by anti-CD3 antibodies and also did not lead to an increase in the relative number of hypodiploid 
cells. Therefore, $\mathrm{CB}[6]$ and $\mathrm{CB}[7]$, at the concentrations used, do not affect the percentage of PBMCs in different phases of the cell cycle.

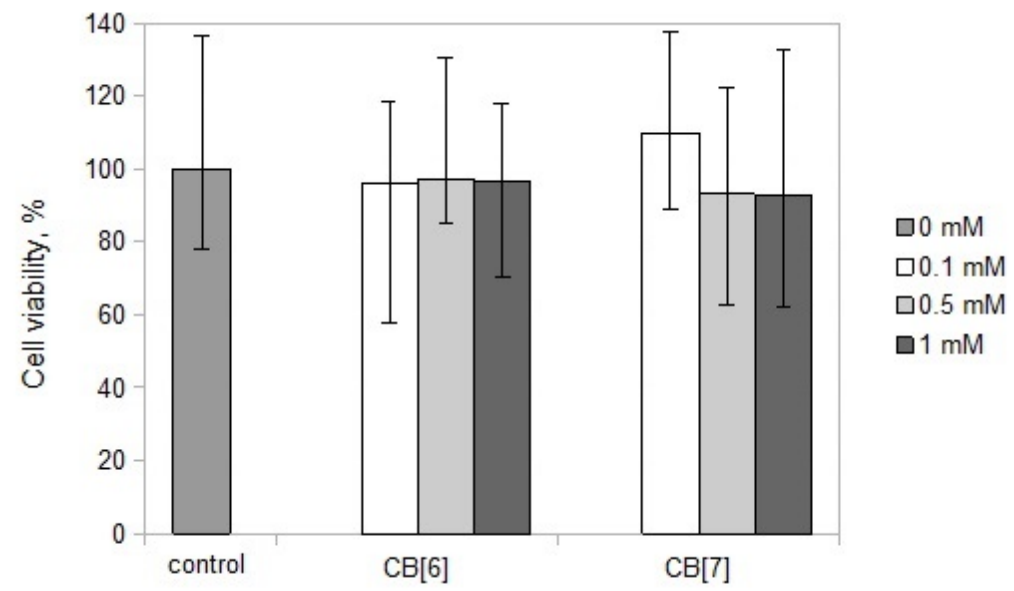

Figure 1. Viability of peripheral blood mononuclear cells (PBMCs) with or without cucurbit[n]uril $(\mathrm{CB}[\mathrm{n}])$ at different concentrations. Data are presented as the median with interquartile range.

Table 1. Relative number of cells in different phases of the cell cycle during the spontaneous proliferative activity of PBMCs cultured for $72 \mathrm{~h}$ in the presence of various concentrations of $\mathrm{CB}[\mathrm{n}]$. Data are presented as the median with interquartile range.

\begin{tabular}{ccccc}
\hline & Sub-G $_{\mathbf{1}} / \mathrm{G}_{\mathbf{0}}$ & $\mathrm{G}_{\mathbf{1}} / \mathrm{G}_{\mathbf{0}}$ & $\mathrm{S}$ & $\mathrm{G}_{\mathbf{2}}$ \\
\hline Control & $0.6(0.4-1.6)$ & $98.7(95.7-99.3)$ & $0.6(0.3-2.5)$ & $0.2(0.1-0.4)$ \\
\hline $\mathrm{CB}[6] 0.1 \mathrm{mM}$ & $1.0(0.3-2.0)$ & $97.9(96.7-98.9)$ & $0.8(0.6-1.4)$ & $0.1(0.1-0.2)$ \\
\hline $\mathrm{CB}[6] 0.3 \mathrm{mM}$ & $1.1(0.4-5.0)$ & $97.2(88.6-97.9)$ & $1.3(1.0-6.1)$ & $0.6(0.3-0.8)$ \\
\hline $\mathrm{CB}[6] 0.5 \mathrm{mM}$ & $0.6(0.3-11.7)$ & $97.7(79.8-98.6)$ & $1.3(1.1-7.7)$ & $0.5(0.2-1.0)$ \\
\hline $\mathrm{CB}[7] 0.1 \mathrm{mM}$ & $0.2(0.1-0.3)$ & $99.2(99.0-99.5)$ & $0.3(0.3-0.6)$ & $0.1(0.1-0.3)$ \\
\hline $\mathrm{CB}[7] 0.3 \mathrm{mM}$ & $1.2(0.2-6.4)$ & $96.6(91.0-98.6)$ & $1.9(1.1-2.4)$ & $0.2(0.2-0.3)$ \\
\hline $\mathrm{CB}[7] 0.5 \mathrm{mM}$ & $1.2(0.3-2.4)$ & $98.0(93.1-99.2)$ & $0.7(0.5-4.1)$ & $0.2(0.1-0.3)$ \\
\hline
\end{tabular}

Table 2. Relative number of cells in different phases of the cell cycle during anti-CD3-induced proliferative activity of PBMCs cultured for $72 \mathrm{~h}$ in the presence of different concentrations of CB[n]. Data are presented as the median with interquartile range.

\begin{tabular}{ccccc}
\hline & Sub-G $_{1} / \mathrm{G}_{\mathbf{0}}$ & $\mathrm{G}_{\mathbf{1}} / \mathrm{G}_{\mathbf{0}}$ & $\mathrm{S}$ & $\mathrm{G}_{\mathbf{2}}$ \\
\hline Control & $2.8(1.3-5.7)$ & $56.4(55.1-69.6)$ & $30.4(20.6-31.9)$ & $9.5(7.8-10.1)$ \\
\hline $\mathrm{CB}[6] 0.1 \mathrm{mM}$ & $4.4(2.3-5.4)$ & $58.6(55.5-72.7)$ & $27.8(17.7-31.7)$ & $8.4(6.4-9.2)$ \\
\hline $\mathrm{CB}[6] 0.3 \mathrm{mM}$ & $3.3(2.0-4.6)$ & $58.4(52.5-74.4)$ & $28.0(16.9-33.4)$ & $9.1(5.4-10.9)$ \\
\hline $\mathrm{CB}[6] 0.5 \mathrm{mM}$ & $3.5(2.0-4.5)$ & $58.5(52.9-72.5)$ & $28.7(19.0-33.1)$ & $8.6(6.5-9.7)$ \\
\hline $\mathrm{CB}[7] 0.1 \mathrm{mM}$ & $2.3(1.1-3.5)$ & $61.3(54.1-76.8)$ & $28.1(16.5-31.7)$ & $8.3(5.3-11.2)$ \\
\hline $\mathrm{CB}[7] 0.3 \mathrm{mM}$ & $2.8(1.4-3.5)$ & $59.6(54.0-74.1)$ & $28.2(18.2-32.1)$ & $8.8(6.1-10.7)$ \\
\hline $\mathrm{CB}[7] 0.5 \mathrm{mM}$ & $3.9(1.7-5.4)$ & $58.8(56.5-75.6)$ & $27.1(16.3-29.7)$ & $8.1(5.1-9.6)$ \\
\hline
\end{tabular}

The effect of $\mathrm{CB}[\mathrm{n}]$ on the proliferation of T-lymphocytes was evaluated on days 3 and 7 . The study was performed both with and without stimulation of cell proliferation using anti-CD3 antibodies in combination with IL-2. It was found that $\mathrm{CB}[\mathrm{n}]$ at all studied concentrations did not affect the proliferative activity of T-lymphocytes at day 3 (Figure 2). However, CB[6] enhanced both spontaneous 
and anti-CD3-induced proliferation of T-lymphocytes at day 7 of cultivation. $C B[7]$ increased the stimulated proliferation of T-lymphocytes at concentrations of 0.1 and $0.3 \mathrm{mM}$, but not $0.5 \mathrm{mM}$. It is known that another cavitand, methyl- $\beta$-cyclodextrin, can also enhance the proliferation of PBMCs [23].

A

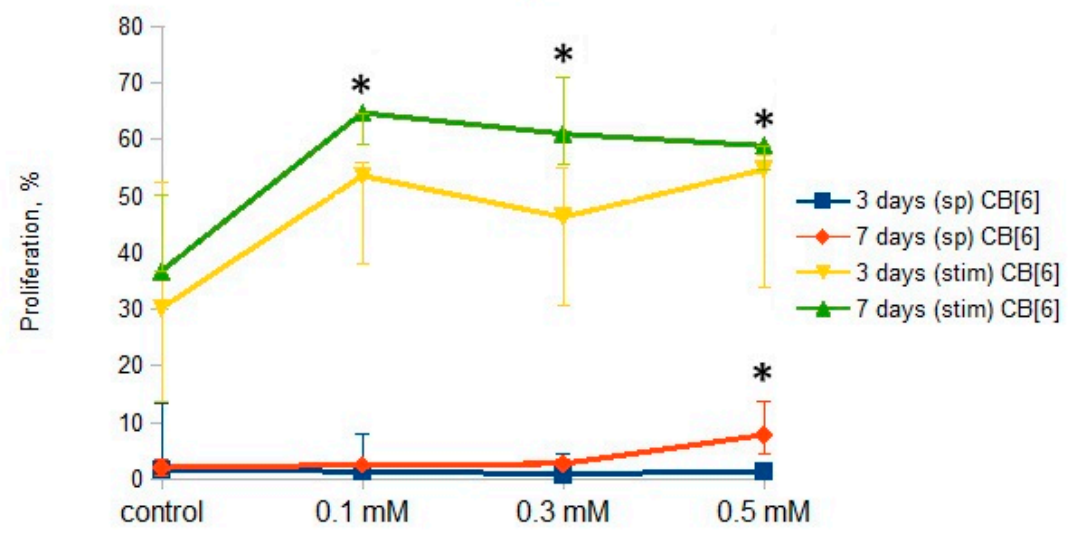

B

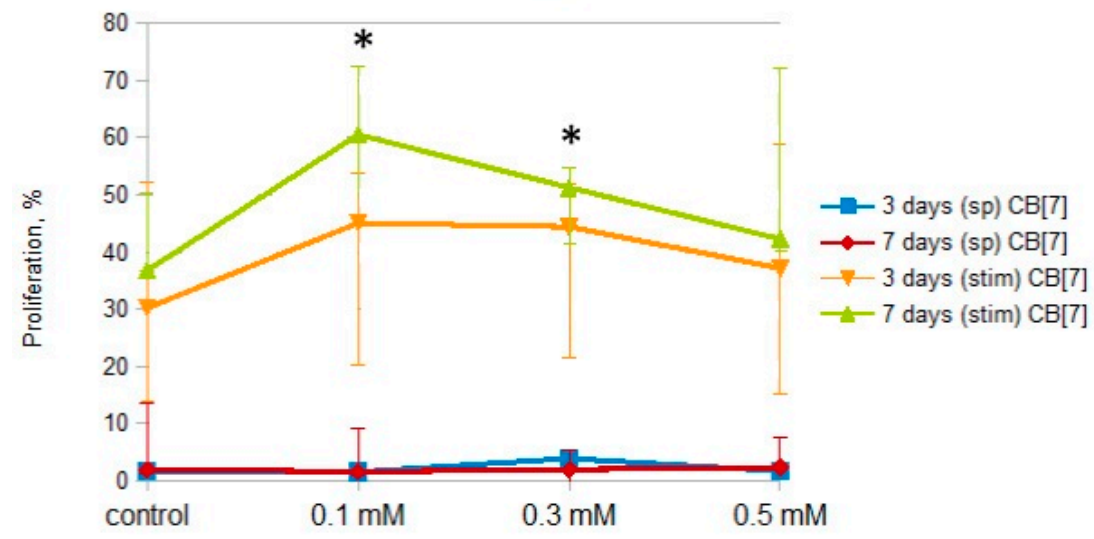

Figure 2. Effect of $\mathrm{CB}[\mathrm{n}]$ on the relative number of proliferating $\mathrm{T}$ cells. (A): Effect of $\mathrm{CB}[6]$ on the relative number of proliferating T cells. (B): Effect of $\mathrm{CB}$ [7] on the relative number of proliferating $\mathrm{T}$ cells. Data are presented as the median with interquartile range. $\left({ }^{*}\right.$ Indicates a significant difference $(p<0.05)$ vs. the control. (sp)—Spontaneous proliferation; (stim)-Anti-CD3-stimulated proliferation.

The next step was to evaluate the effect of various concentrations of $\mathrm{CB}[\mathrm{n}]$ on the percentage of T-helper cells and cytotoxic T-lymphocytes (Figures 3 and 4). $\mathrm{CB}[\mathrm{n}]$ had practically no effect on the number of T-helper cells and cytotoxic T-lymphocytes at days 1 and 7 of cultivation. However, $0.3 \mathrm{mM}$ $\mathrm{CB}[6]$ in a stimulated culture led to a slight decrease in the number of T-helper cells (Figure 3) and a proportional increase in the number of cytotoxic T-lymphocytes (Figure 4) at day 1 of cultivation. Interestingly, this effect was not observed with further cultivation (day 7). 


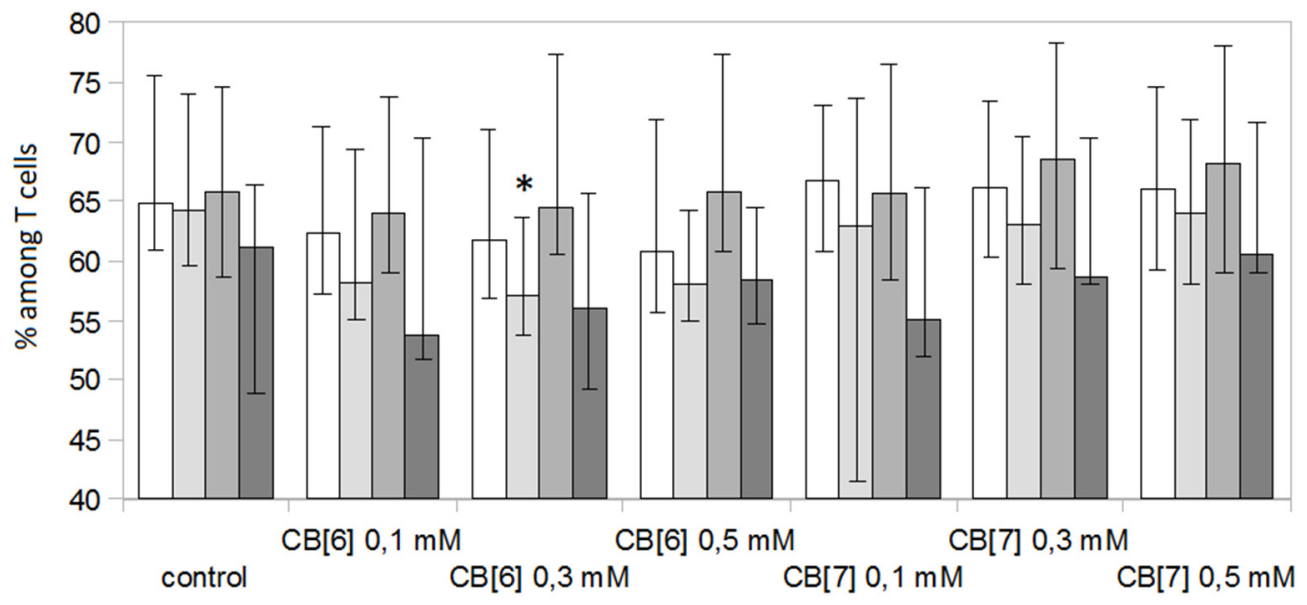

$\square$ 1st day $\square$ 1st day (act) $\square$ 7th day $\square$ 7th day (act)

Figure 3. Percentage of $\mathrm{CD}^{+} \mathrm{CD}^{+}$T-helper cells in PBMCs cultivated in the presence of $\mathrm{CB}[\mathrm{n}]$ at various concentrations. Data are presented as the median with interquartile range. ${ }^{*}$ Indicates a significant difference $(p<0.05)$ vs. the control. (act) - Culture of PBMCs activated with anti-CD3 antibodies.

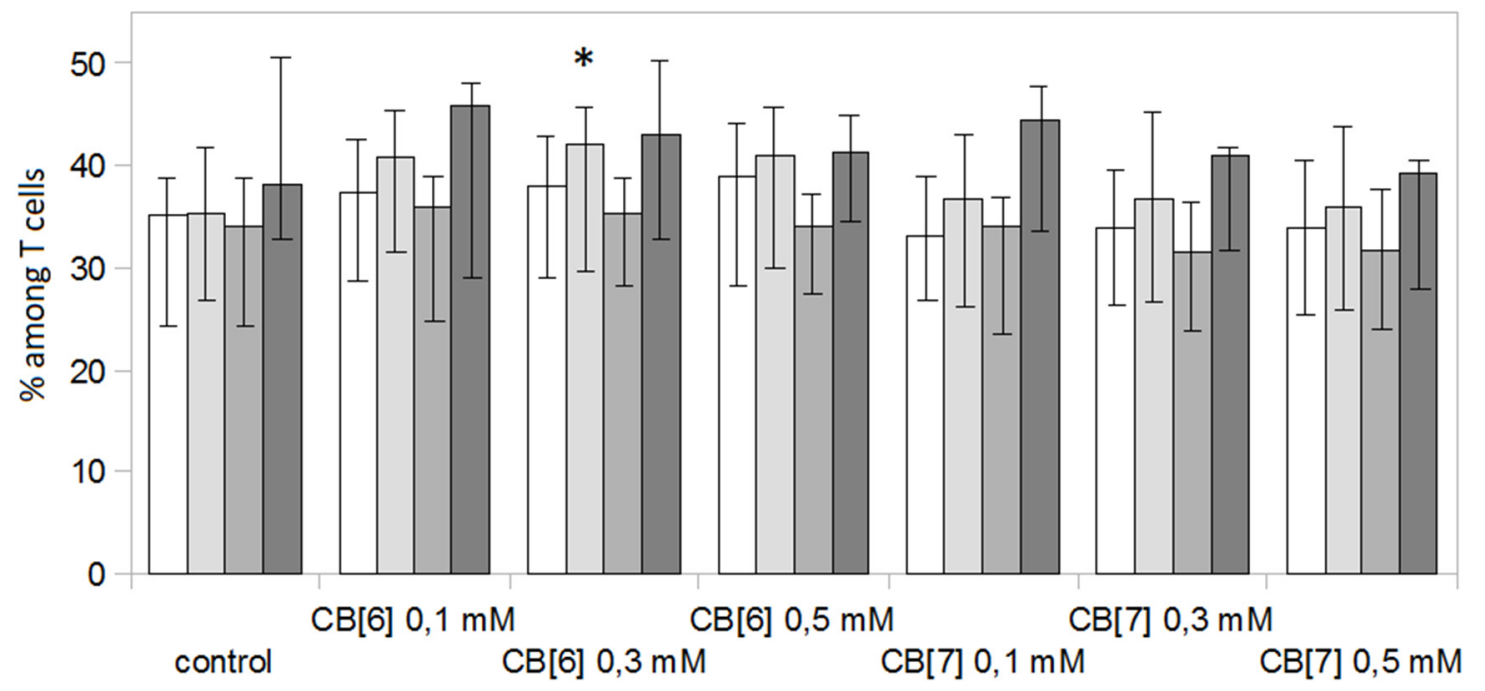

$\square$ 1st day $\square$ 1st day (act) $\square$ 7th day $\square$ 7th day (act)

Figure 4. Percentage of $\mathrm{CD}^{+} \mathrm{CD}^{-}$cytotoxic T cells in PBMCs cultivated in the presence of various concentrations of $\mathrm{CB}[\mathrm{n}]$. Data are presented as the median with interquartile range. (* Indicates a significant difference $(p<0.05)$ vs. the control. (act) - Culture of PBMCs activated with anti-CD3 antibodies.

In addition, we investigated the effect of $\mathrm{CB}[\mathrm{n}]$ on early (CD69) and late (HLA-DR) markers of lymphocyte activation (Figures 5 and 6). $\mathrm{CB}[\mathrm{n}]$ did not lead to a change in the level of expression of CD69 on T-lymphocytes. However, it should be noted that significant differences $(p<0.05)$ in the expression of this molecule were observed in individual donors. $\mathrm{CB}[\mathrm{n}]$ increased the expression of HLA-DR on $\mathrm{CD}^{+} \mathrm{CD}^{-}$cells and decreased the expression of HLA-DR on $\mathrm{CD} 3^{+} \mathrm{CD} 4^{+} \mathrm{T}$ lymphocytes in anti-CD3 stimulated culture. In addition, $\mathrm{CB}[\mathrm{n}]$ increased the levels of HLA-DR on T-helper cells and cytotoxic $\mathrm{T}$ cells not activated with anti-CD3 antibodies. 


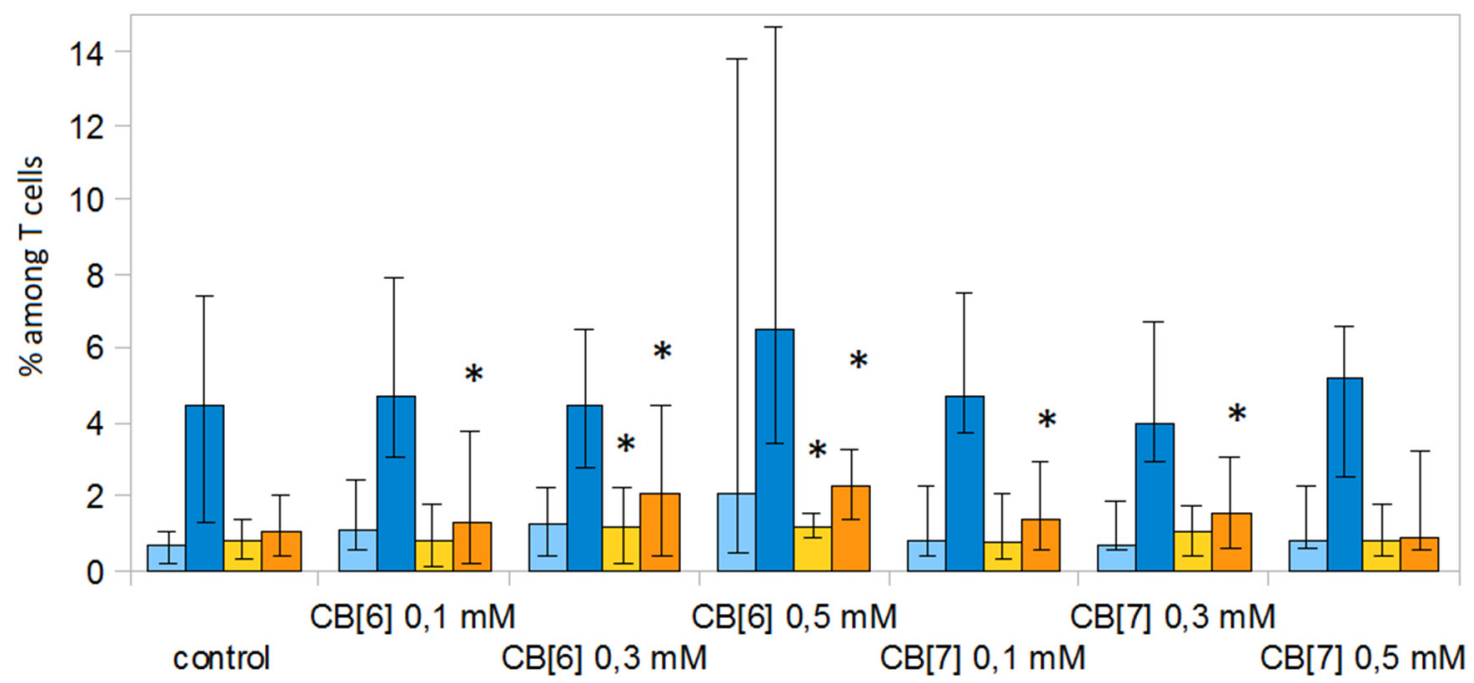

$\square \mathrm{CD} 3+\mathrm{CD} 4+\mathrm{CD} 69+\square \mathrm{CD} 3+\mathrm{CD} 4-\mathrm{CD} 69+\square \mathrm{CD} 3+\mathrm{CD} 4+\mathrm{HLA}-\mathrm{DR}+\square \mathrm{CD} 3+\mathrm{CD} 4-\mathrm{HLA}-\mathrm{DR}+$

Figure 5. Effect of $\mathrm{CB}[\mathrm{n}]$ on the expression of activation markers on $\mathrm{T}$ cells during the spontaneous proliferative activity of PBMCs. Data are presented as the median with interquartile range. (* Indicates a significant difference $(p<0.05)$ vs. the control).

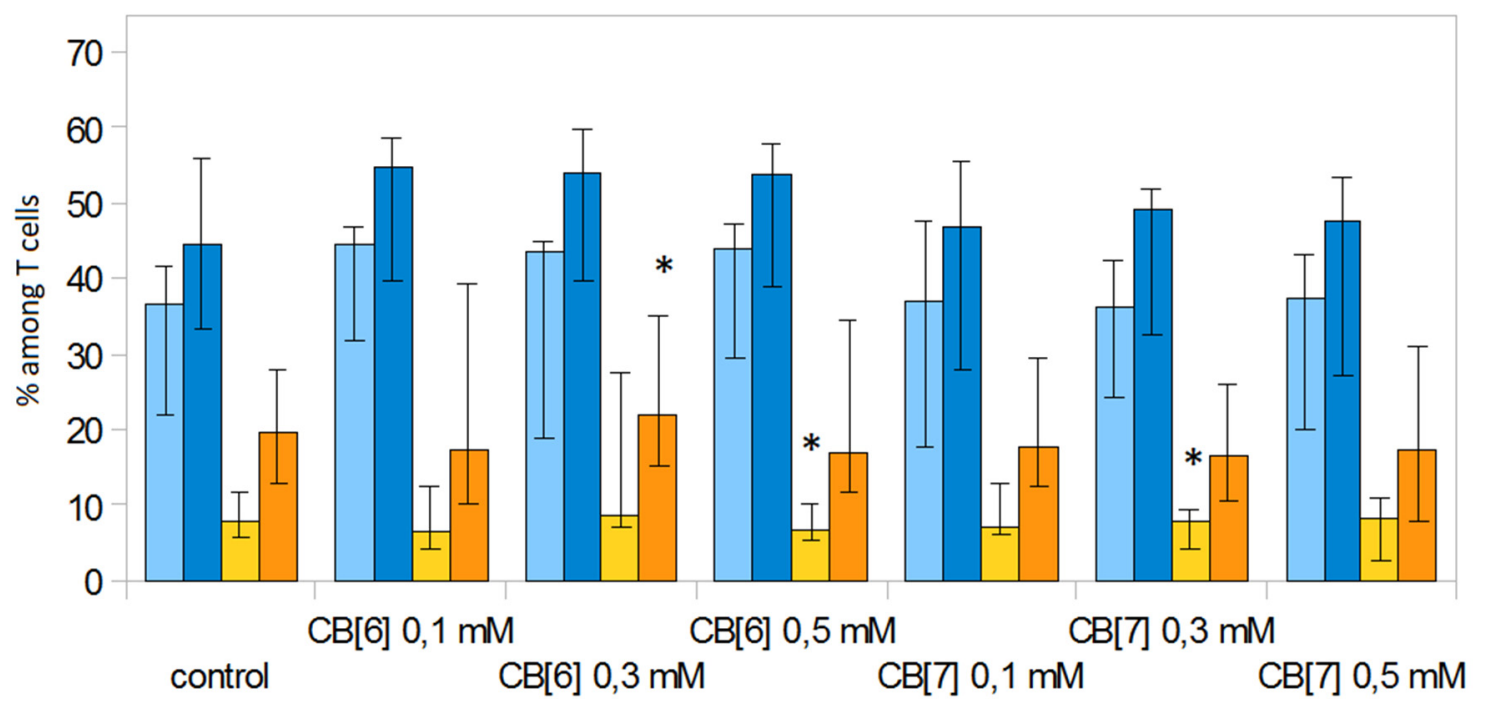

$\square \mathrm{CD} 3+\mathrm{CD} 4+\mathrm{CD} 69+\square \mathrm{CD} 3+\mathrm{CD} 4-\mathrm{CD} 69+\square \mathrm{CD} 3+\mathrm{CD} 4+\mathrm{HLA}-\mathrm{DR}+\square \mathrm{CD} 3+\mathrm{CD} 4-\mathrm{HLA}-\mathrm{DR}+$

Figure 6. Effect of $\mathrm{CB}[\mathrm{n}]$ on the expression of activation markers on T cells during anti-CD3-induced proliferative activity of PBMCs. ( Indicates a significant difference $(p<0.05)$ vs. the control).

Surprisingly, CB[6] at all studied doses increased the expression of HLA-DR on B lymphocytes after seven days of cultivation (Figure 7). These data indicate a possible effect of CB[6] on humoral immunity or the antigen presentation process. Other cavitands can also enhance the expression of CLA on antigen-presenting cells [24]. Thus, further research is required to identify the mechanism of enhancement of the HLA-DR expression. 


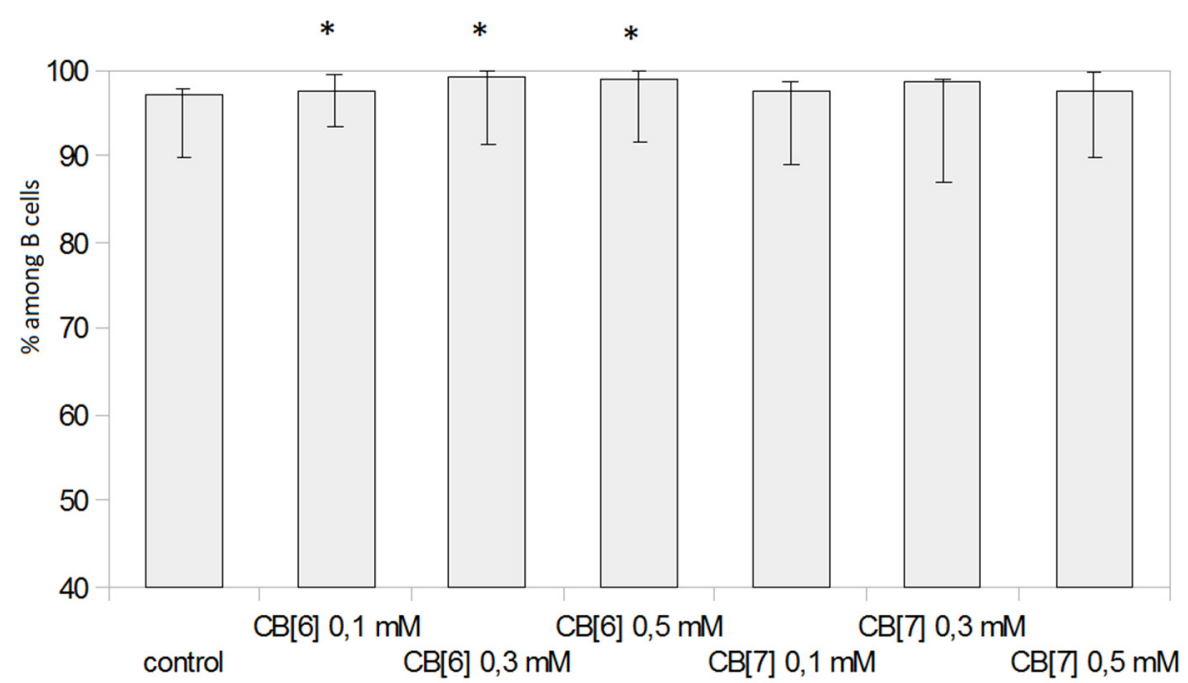

Figure 7. Effect of $\mathrm{CB}[\mathrm{n}]$ on the HLA-DR expression on $\mathrm{CD} 19+\mathrm{B}$ cells after seven days of cultivation. ( ${ }^{*}$ Indicates a significant difference $(p<0.05)$ vs. the control.)

\section{Materials and Methods}

\subsection{Materials}

CB[6] and CB[7] were synthesized at the Nikolaev Institute of Inorganic Chemistry SB RAS (Novosibirsk, Russia) through the standard procedure described in [25]. The structures of $\mathrm{CB}[6]$ and $\mathrm{CB}$ [7] were verified with ${ }^{1} \mathrm{H}$ NMR in $\mathrm{D}_{2} \mathrm{O}$ at $25{ }^{\circ} \mathrm{C}$ (Figure S2 in Supplementary) using a $500 \mathrm{MHz}$ Bruker Avance III spectrometer. Medium, phosphate-buffered saline, and L-glutamine were obtained from Biolot (Saint Petersburg, Russia). HyClone fetal calf serum was obtained from GE Healthcare (Chicago, IL, USA). WST-1 reagent was purchased from Takara Bio Inc. (Kusatsu, Japan). Anti-CD3 antibody was obtained from MedBioSpectr (Moskow, Russia). Recombinant IL-2 was obtained from Biotech (Saint Petersburg, Russia).

\subsection{Isolation and Cultivation of Peripheral Blood Mononuclear Cells (PBMCs)}

The venous blood of 22 healthy donors (mean age: $36.0 \pm 2.48$ years) was used in the study. Donor blood was obtained at the donor center of the State Budgetary Healthcare Institution of the Novosibirsk Oblast "City Clinical Hospital №1". All the participants signed an informed consent form approved by the local ethics committee of the Research Institute of Fundamental and Clinical Immunology. PBMCs were isolated by the standard method by centrifugation of blood in a Ficoll-Urografin density gradient $\left(\rho=1.077 \mathrm{~g} / \mathrm{cm}^{3}\right)$ [26]. Cultivation of PBMCs was carried out in flat-bottom well plates (Costar, New York, NY, USA) at a concentration of $1 \mathrm{million} / \mathrm{mL}$ in Roswell Park Memorial Institute (RPMI-1640) (Biolot, St Petersburg, Russia) culture medium containing 0.3\% L-glutamine (Biolot, St Petersburg, Russia), $50 \mu \mathrm{g} / \mathrm{mL}$ gentamicin (DalChimPharm, Russia), $25 \mu \mathrm{g} / \mathrm{mL}$ thienam (Merck Sharp \& Dohme, Haarlem, The Netherlands), and 10\% inactivated fetal calf serum (HyClone, Chicago, IL, USA) at $37^{\circ} \mathrm{C}$ under $5 \% \mathrm{CO}_{2}$ in air with high humidity.

\subsection{Cell Viability}

The cell viability was evaluated after incubation with different concentrations of $\mathrm{CB}[6]$ and $\mathrm{CB}[7]$ $(1,0.5$, and $0.1 \mathrm{mM})$ using the WST-1 method. PBMCs were seeded at $10^{5}$ cells/well into a flat-bottomed, 96-well plate. After $72 \mathrm{~h}$ of cultivation, $10 \mu \mathrm{L}$ of WST-1 (Takara Bio, Kusatsu, Japan) stock solution was added into each well containing $100 \mu \mathrm{L}$ of cell suspension. The absorbance was directly read at $450 \mathrm{~nm}$, and the reference was read at $620 \mathrm{~nm}$. 


\subsection{Cell Cycle Analysis}

Analysis of the PBMC cell cycle distribution was performed after $72 \mathrm{~h}$ of incubation with or without different concentrations of $\mathrm{CB}[\mathrm{n}](0.5,0.3$, and $0.1 \mathrm{mM})$. After cultivation, the PBMCs were washed from the medium with phosphate-buffered saline (Biolot, St Petersburg, Russia). Then, cells were fixed overnight at $-20^{\circ} \mathrm{C}$ in $70 \%$ ethanol and stained with propidium iodide $(100 \mu \mathrm{g} / \mathrm{mL})$ in the presence of RNAse A $(100 \mu \mathrm{g} / \mathrm{mL})$ for $30 \mathrm{~min}$ at $37^{\circ} \mathrm{C}$. Cell cycle analysis was conducted by evaluating DNA histograms. Samples were analyzed on a FACSCanto II flow cytometer (Becton Dickinson, Franklin Lakes, NJ, USA) and ModFit 3.2 software (Verity Software House, Topsham, ME, USA). The relative amounts of cells with diploid (cells in $G_{0} / G_{1}$ phases of the cell cycle) and hyperdiploid (cells in $\mathrm{S}$ and $\mathrm{G}_{2} / \mathrm{M}$ phases of the cell cycle) DNA sets were determined. Cells with fragmented DNA formed a characteristic hypodiploid peak.

\subsection{T Cell Analysis}

PBMCs were cultivated with different concentrations of $\mathrm{CB}[6]$ and $\mathrm{CB}[7](0.5,0.3$, and $0.1 \mathrm{mM})$ in the presence or absence of anti-CD3 antibody $(1 \mu \mathrm{g} / \mathrm{mL})$ and recombinant human IL-2 (100 units/mL). The proliferation of PBMCs was assessed by flow cytometry of carboxyfluorescein succinimidyl ester (CFSE) stained cells. Cells were labeled before culture with 5,6-carboxyfluorescein diacetate succinimidyl ester (CFSE) $(4 \mu \mathrm{M})$ (Invitrogen, Eugene, OR, USA), mixed well and incubated for $15 \mathrm{~min}$ in darkness, stirring occasionally. Then the reaction was stopped by adding $2 \mathrm{~mL}$ of PBS with $5 \%$ FCS, followed by centrifugation. To evaluate the proliferation of lymphocyte subsets, PBMCs after cultivation were stained with monoclonal anti-human antibodies (CD45-PE/Cy7, CD3-APC, CD4-PerCP/Cy5.5, and CD19-APC/Cy7) all from BioLegend, (San Diego, CA, USA). Analyses were performed using a FACSCanto II (Becton Dickinson, USA) and FACSDiva software (Becton Dickinson, USA). The analysis of proliferating activity was carried out after three and seven days of cultivation.

\subsection{Expression of Activation Molecules}

Cells were treated with $\mathrm{CB}[\mathrm{n}]$ at different concentrations and cultured for $24 \mathrm{~h}$ or $1 \mathrm{w}$ to evaluate early (CD69) and late (HLA-DR) activation markers, respectively. After cultivation, cells were stained with fluorochrome-labeled antibodies (CD69-PE or HLA-DR-PE, all from BioLegend).

\subsection{Statistical Analysis}

All data from experiments were expressed as median (25th-75th percentile). ANOVA analyses were performed using GraphPad Prism, with post-hoc comparisons carried out by Fisher's protected least significant difference tests. A $p$-value $<0.05$ was regarded as the minimum criterion for statistical significance.

\section{Conclusions}

Our results showed that $\mathrm{CB}[\mathrm{n}](n=6$ and 7$)$ did not affect the viability of PBMCs. In the case of a short cultivation time (1-3 days), $\mathrm{CB}[\mathrm{n}]$ did not have an appreciable effect on the proliferation and phenotypic characteristics of the PBMCs. After a longer cultivation time, $\mathrm{CB}[\mathrm{n}]$ had an immunostimulating effect, enhancing the proliferative activity of cells and increasing the expression of HLA-DR on lymphocytes. It is important to note that $\mathrm{CB}[\mathrm{n}]$ did not have an immunosuppressive effect, with the exception of a slight decrease in HLA-DR expression on T-helper cells in stimulated cultures.

Supplementary Materials: The Supplementary Materials are available online.

Author Contributions: Conceptualization, V.K., E.K. and E.P.; methodology, V.K., E.P., E.B., I.M., E.K., N.K., A.A., A.E.; validation, V.K., E.P. and E.B..; investigation, V.K., E.P., A.A., A.E., E.B., N.K., E.K., I.M.; writing-original draft preparation, E.P.; writing-review and editing, E.P., V.K., N.K., A.A.; supervision, V.K.; project administration, V.K.; funding acquisition, V.K. All authors have read and agreed to the published version of the manuscript.

Funding: This study was funded by the Russian Science Foundation according to research project No. 19-15-00192. Conflicts of Interest: The authors declare no conflicts of interest. 


\section{References}

1. Ye, C.; Chi, H. A review of recent progress in drug and protein encapsulation: Approaches, applications and challenges. Mater. Sci. Eng. C. 2018, 83, 233-246. [CrossRef]

2. Geng, W.C.; Sessler, J.L.; Guo, D.S. Supramolecular prodrugs based on host-guest interactions. Chem. Soc. Rev. 2020, 49, 2303-2315. [CrossRef] [PubMed]

3. McInnes, F.J.; Anthony, N.G.; Kennedy, A.R.; Wheate, N.J. Solid state stabilisation of the orally delivered drugs atenolol, glibenclamide, memantine and paracetamol through their complexation with cucurbit[7]uril. Org. Biomol. Chem. 2010, 8, 765-773. [CrossRef] [PubMed]

4. Robinson, E.L.; Zavalij, P.Y.; Isaacs, L. Synthesis of a disulfonated derivative of cucurbit[7]uril and investigations of its ability to solubilize insoluble drugs. Supramol. Chem. 2015, 27, 288-297. [CrossRef] [PubMed]

5. Saleh, N.; Koner, A.L.; Nau, W.M. Activation and stabilization of drugs by supramolecular pKa shifts: Drug delivery applications tailored for cucurbiturils. Angew. Chem. Int. Ed. 2008, 47, 5398-5401. [CrossRef] [PubMed]

6. Zhang, B.; Isaacs, L. Acyclic cucurbit[n]uriltype molecular containers: Influence of aromatic walls on their function as solubilizing excipients for insoluble drugs. J. Med. Chem. 2014, 57, 9554-9563. [PubMed]

7. Knauer, N.E.; Pashkina, E. Apartsin topological aspects of the design of nanocarriers for therapeutic peptides and proteins. Pharmaceutics 2019, 11, 91. [CrossRef] [PubMed]

8. Mirzaeva, I.V.; Andrienko, I.V.; Kovalenko, E.A.; Pashkina, E.A.; Aktanova, A.A. ${ }^{1}$ H NMR study of the effect of cucurbit[7]uril on the hydrolysis of carboplatin in biologically relevant media. Appl. Magn. Reson. 2019, 50, 1267-1276. [CrossRef]

9. Gerasko, O.A.; Kovalenko, E.A.; Fedin, V.P. Macrocyclic cavitands cucurbit[n]urils: Application prospects in biochemistry, medicine, and nanotechnology. Russ. Chem. Rev. 2016, 85, 795-816. [CrossRef]

10. Wheate, N.J.; Buck, D.P.; Day, A.I.; Collins, J.G. Cucurbit[n]uril binding of platinum anticancer complexes. Dalton trans. 2006, 451-458. [CrossRef]

11. Jeon, Y.J.; Kim, S.Y.; Ko, Y.H.; Sakamoto, S.; Yamaguchi, K.; Kim, K. Novel molecular drug carrier: Encapsulation of oxaliplatin in cucurbit[7]uril and its effects on stability and reactivity of the drug. Org. Biomol. Chem. 2005, 3, 2122-2125. [CrossRef] [PubMed]

12. Kovalenko, E.A.; Pashkina, E.A.; Kanazhevskaya, L.Y.; Masliy, A.N.; Kozlov, V.A. Chemical and biological properties of a supramolecular complex of tuftsin and cucurbit[7]uril. Int. Immunopharmacol. 2017, 47, 199-205. [CrossRef] [PubMed]

13. Das, D.; Assaf, K.I.; Nau, W.M. Applications of cucurbiturils in medicinal chemistry and chemical biology. Front. Chem. 2019, 7, 619-631. [CrossRef] [PubMed]

14. Yang, X.; Wang, Z.; Niu, Y.; Chen, X.; Lee, S.M.Y.; Wang, R. Influence of supramolecular encapsulation of camptothecin by cucurbit[7]uril: Reduced toxicity and preserved anti-cancer activity. MedChemComm 2016, 7, 1392-1397. [CrossRef]

15. Li, S.; Chan, J.Y.-W.; Li, Y.; Bardelang, D.; Zheng, J.; Yew, W.W.; Chan, D.P.-C.; Lee, S.M.Y.; Wang, R. Complexation of clofazimine by macrocyclic cucurbit[7]uril reduced its cardiotoxicity without affecting the antimycobacterial efficacy. Org. Biomol. Chem. 2016, 14, 7563-7569. [CrossRef]

16. Hettiarachchi, G.; Nguyen, D.; Wu, J.; Lucas, D.; Ma, D.; Isaacs, L.; Briken, V. Toxicology and drug delivery by cucurbit[n]uril type molecular containers. PLOS ONE 2010, 6, e10514. [CrossRef]

17. Uzunova, V.D.; Cullinane, C.; Brix, K.; Nau, W.M.; Day, A.I. Toxicity of cucurbit[7]uril and cucurbit[8]uril: An exploratory in vitro and in vivo study. Org. Biomol. Chem. 2010, 8, 2037-2042. [CrossRef]

18. Chen, H.; Chan, J.Y.W.; Yang, X.; Wyman, I.W.; Macartney, D.H.; Bardelang, D.; Lee, S.M.Y.; Wang, R. Developmental and organspecific toxicity of cucurbit[7]uril: In vivo study on zebrafish models. RSC Adv. 2015, 5, 30067-30074. [CrossRef]

19. Chen, H.; Chan, J.Y.W.; Li, S.; Liu, J.J.; Wyman, I.W.; Lee, S.M.Y.; Macartney, D.H.; Wang, R. In vivo reversal of general anesthesia by cucurbit[7] uril with zebrafish models. RSC Adv. 2015, 5, 63745-63752. [CrossRef]

20. Miao, X.; Li, Y.; Wyman, I.W.; Lee, S.M.Y.; Macartney, D.H.; Zheng, Y.; Wang, R. Enhanced in vitro and in vivo uptake of a hydrophobic model drug coumarin-6-in the presenceof cucurbit[7]uril. Med. Chem. Commun. 2015, 6, 1370-1374. [CrossRef] 
21. Oun, R.; Floriano, R.S.; Isaacs, L.; Rowana, E.G.; Wheate, N.J. The ex vivo neurotoxic, myotoxic and cardiotoxic activity of cucurbiturilbased macrocyclic drug delivery vehicles. Toxicol. Res. 2014, 3, 447-455. [CrossRef] [PubMed]

22. Zhang, X.; Xu, X.; Li, S.; Wang, L.H.; Zhang, J.; Wang, R. A systematic evaluation of the biocompatibility of cucurbit[7]uril in mice. Sci. Rep. 2018, 8, 8819-8825. [CrossRef] [PubMed]

23. Lü, H.Z.; Zhu, A.Y.; Chen, Y.; Tang, J.; Li, B.Q. Lower Concentrations of Methyl- $\beta$-Cyclodextrin Combined With interleukin-2 Can Preferentially Induce Activation and Proliferation of Natural Killer Cells in Human. Peripheral Blood. Hum. Immunol. 2011, 72, 538-546. [CrossRef] [PubMed]

24. Kim, S.K.; Yun, C.-H.; Han, S.H. Induction of Dendritic Cell Maturation and Activation by a Potential Adjuvant, 2-Hydroxypropyl- $\beta$-Cyclodextrin. Front. Immunol. 2016, 7, 435-444. [CrossRef]

25. Day, A.; Arnold, A.P.; Blanch, R.J.; Snushall, B. Controlling factors in the synthesis of cucurbituril and its homologues. J. Org. Chem. 2001, 66, 8094-8100. [CrossRef] [PubMed]

26. Böyum, A. Separation of leukocytes from blood and bone marrow. Scand. J. Clin. Lab. Investig. Suppl. 1968, 97,77-89. [PubMed]

Sample Availability: Samples of all compounds are available from the authors. 